\title{
Pemetaan Daerah Penangkapan Ikan Dengan Pendekatan Ruang Di Perairan Kabupaten Sumba Timur
}

\author{
Ihsan ${ }^{1)}$ dan Mustamin Tajuddin ${ }^{2)}$ \\ ${ }^{1)}$ Ketua dan Dosen Program studi Pemanfaatan Sumberdaya Perikanan FPIK UMI Makassar \\ ${ }^{2)}$ Anggota dan Dosen Prodi Pemanfaatan Sumberdaya Perikanan FPIK UMI Makassar \\ E-mail: ihsanpsp@yahoo.co.id
}

\begin{abstract}
ABSTRAK
Perairan Kabupaten Sumba Timur yang begitu luas menyebabkan distribusi dan sebaran potensi perikanan tangkap sulit untuk dimanfaatkan, oleh karena itu diperlukan adanya suatu peta daerah penangkapan ikan yang jelassehingga para nelayan dapat dengan muda melakukan penangkapan ikan. Penelitian ini bertujuan untuk pemetaan daerah penangkapan ikan dengan pendekatan ruang di perairan Kabupaten Sumba Timur. Kabupaten Sumba Timur memiliki wilayah perairan laut yang luas dan potensi sumberdaya perikanan tangkap yang sangat melimpah, dan produksi ikan tahun 2014, belum optimal. Hasil analisis kesesuaian daerah penangkapan ikan pelagis ditetapkan "sangat sesuai" (S1) 163.464,47 Ha, "sesuai" (S2) 44.724,60 Ha, kurang sesuai (S3) 11.707,62. Kesesuaian daerah penangkapan ikan demersal pada kriteria "sangat sesuai" (S1) 7.109,89 Ha, "sesuai" (S2) 6.386,77 Ha, dan kurang sesuai (S3) 11.233,14 Ha.
\end{abstract}

KATA KUNCI: Analisis; Daerah Penangkapan Ikan; Pendekatan; Ruang.

\begin{abstract}
East SumbaWaters is so wide, the distribution and the spread of fishery potential is difficult to exploit, therefore it is necessary to have a map of the fishing area clearlyso that the fishermen can easily engaging in fishing activities. This study aims to mapping the fishing area with space approach in the waters of East Sumba District. The results of the analysis of the suitability of pelagic fishing area designated "very appropriate" (S1) 163.464,47 Ha, "appropriate" (S2) 44.724,60 ha, less suitable (S3) 11.707,62. Suitability demersal fishing areas on the criteria of "very appropriate" (S1) 7.109,89 Ha, "appropriate" (S2) 6.386,77 Ha, and less suitable (S3) 11.233,14 Ha.
\end{abstract}

KEYWORDS: Analysis; Fishing areas; Approach; Space. 


\section{Pendahuluan}

Wilayah pesisir dan pulau-pulau kecil, yang terdapat ekosistem mangrove, padang lamun dan terumbu karang, menyebabkan wilayah pesisir memiliki produktivitas hayati yang tinggi, dan berperan penting sebagai penunjang sumberdaya ikan. Diantara sekian banyak potensi yang ada di wilayah pesisir dan pulau-pulau kecil di Kabupaten Sumba Timur maka potensi yang terkenal adalah perikanan dan kelautan.

Luas Kabupaten Sumba Timur adalah sekitar $7000 \mathrm{~km}^{2}$, memiliki panjang pantai 433,6 km. Luas pesisir laut Kabupaten Sumba Timur sekitar 2.973 $\mathrm{km}^{2}$. Potensi pembangunan yang terdapat di wilayah pesisir dan lautan secara garis besar terdiri dari tiga kelompok : (1) sumber daya dapat pulih (renewable resources), (2) sumber daya tak dapat pulih (non-renewable resources), dan jasa-jasa lingkungan (environmental services). Kabupaten Sumba Timur memiliki potensi unggulan, seperti pertanian, perkebunan, kehutanan, kelautan dan perikanan, peternakan dan pertambangan. Jika dilihat dari potensi perikanan tangkap, Kabupaten Sumba Timur kaya akan keanekaragaman hayati laut, baik sumberdaya ikan pelagis (seperti berbagai jenis tuna, tongkol, cakalang) dan sumberdaya ikan demersal (seperti kerapu, hiu, berbagai jenis ikan karang, udang).
Penyebaran ikan pelagis dan demersal tersebut hampir di seluruh perairan pantai, terutama pantai utara (Tanjung Sasar, Tanjung Batu, Modu, Kayuri, Rende, Tapil, Nusa Maukawini, Hanggaroru, Benda, dan Kalala) dan pantai selatan (Tarimbang dan Salura).

Permintaanterhadaphasilperikanan pada Kabupaten Sumba Timur semakin meningkatseiringdenganpertambahanjuml ahpendudukdankesadaranmasyarakatnyate rhadapkebutuhan protein hewani, olehkarenapemenuhankebutuhan protein hewani yang berasal dari ikan merupakan pemenuhan sumber protein yang dapat di jangkau oleh berbagai lapisan masyarakat.

Perairan Kabupaten Sumba Timur yang begitu luas menyebabkan distribusi dan sebaran potensi perikanan tangkap sulit untuk dimanfaatkan oleh karena itu diperlukan adanya suatu peta daerah penangkapan ikan yang jelas sehingga para nelayan dapat dengan muda melakukan penangkapan ikan, baik ikan pelagis maupun ikan demersal. Adanya potensi unggulan dibidang perikanan dan kelautan yang besar di Kabupaten Sumba Timur, jika pemanfaatannya dapat dioptimalkan, akan sangat menguntungkan untuk peningkatan kesejahteraan rakyat. Sehubungan dengan hal tersebut, maka salah hal yang dapat dilakukan penelitian tentang pemetaan daerah penangkapan 
ikan pelagis dengan pendekatan ruangdi perairan Kabupaten Sumba Timur.

Adapun tujuan yang ingindicapai dalam penelitian ini adalah melakukan pemetaan daerah penangkapan ikan dengan pendekatan ruang di perairan Kabupaten Sumba Timur. Sedangkan kegunaanyaadalahterpetakannya daerah penangkapan ikan, sehingga nelayan dengan mudah dalam menangkap ikan di perairan Kabupaten Sumba Timur.

\section{Bahan Dan Metode}

Penelitian ini dilaksanakan di seluruh perairan Kabupaten Sumba Timur, dan pelaksanaan selama 6 bulan. Untuk pemetaan daerah penangkapan ikan, maka dilakukan metode surveidan pengukuran sebanyak 115 titik samplig di perairan. Jenis data yang dikumpulkan terdiri dari data primer dan sekunder. Data primer terdiri dari klorofil, suhu dan salinitas. Sedangkan data sekunder berupa data produksi perikanan tangkap, demografi Kabupaten Sumba Timur, peta RBI, LPI dan citra satelit ASTER (Advanced Spaceborne Thermal Emission and Reflection Radiometer) tahun 2012.Dalam penelitian ini dilakukan berbagai jenis analisis yaitu analisis di Laboratorium dan analisis kualitatif dan kuantitatif.

Untukanalisisdaerah penangkapan ikan dilakukan menggunakan analisis system informasi geografis (SIG). Ihsan (2015) mengatakan bahwa analisis keruangan dalam penelitian ini menggunakan system informasi geografis (SIG) dengan metode ArcView, yaitu system informasi spasial menggunakan komputer yang melibatkan perangkat keras (hardware), perangkat lunak (software), pemakaian data-data yang mempunyai fungsi pokok untuk menyimpan, memperbaharui, menganalis dan menyajikan kembali semua bentuk informasispasial.

\section{Hasil dan Pembahasan}

\subsection{Potensi lestari Perikanan Tangkap}

Wilayah yang berpotensi dalam perikanan tangkap meliputi wilayah pesisir dan laut Kabupaten Sumba Timur. Kabupaten Sumba Timur memiliki wilayahlautseluas $\quad 8.373,53 \quad \mathrm{Km}^{2}$ denganpanjanggarispantai $\quad 433,6 \quad \mathrm{Km}$. Potensi lestari (MSY) perikanan tangkap 66.200 ton/tahun dengan total tangkapan yang diperbolehkan (TAC) 52.300 ton/tahun (DKP Kabupaten Sumba Timur - Masterplan Kawasan Minapolitan Kabupaten Sumba Timur, 2011). Berdasarkan data produksi perikanan tangkap Kabupaten Sumba Timur Tahun 2013, jumlah total produksinya adalah $11.814,80$ ton (DKP Kabupaten Sumba Timur). Hal tersebut menunjukkan bahwa jumlah total produksi perikanan tangkap 
Tahun 2013 masih berada dibawah jumlah tangkapan yang diperbolehkan (JTB) dan masih berpotensi besar dalam pengembangan perikanan tangkap.

\subsection{Produksi Perikanan Tangkap}

Secara eksisting perikanan tangkap merupakan pekerjaan yang menjadi dominan dilakukan oleh masyarakat pesisir di Kabupaten Sumba Timur. Adapun keadaan perikanan tangkap yang dilakukan selama lima tahunyang disajikan padatabel berikut.

Tabel 1. Produksiperikanantangkapberdasarkankecamatandi Kabupaten Sumba Timur, tahun 2008-2012

\begin{tabular}{|c|l|r|r|r|r|r|}
\hline \multirow{2}{*}{ No. } & \multirow{2}{*}{ Kecamatan } & \multicolumn{6}{|c|}{ ProduksiPerikananTangkap (ton) } \\
\cline { 3 - 7 } & & 2008 & 2009 & 2010 & 2011 & \multicolumn{1}{c|}{2012} \\
\hline 1. & LewaTidahu & 39 & 10 & 38,73 & 45,00 & 20,29 \\
\hline 2. & KatalaHamuLingu & 28 & 3 & 28,45 & 33,90 & 34,59 \\
\hline 3. & Tabundung & 447 & 193,5 & 471,48 & 474,63 & 484,24 \\
\hline 4. & PinuPahar & 471 & 251,3 & 446,66 & 440,72 & 449,64 \\
\hline 5. & Karera & 249 & 117 & 248,75 & 248,61 & 253,65 \\
\hline 6. & NgaduNgala & 91 & 231 & 91,39 & 90,40 & 92,23 \\
\hline 7. & PahungaLodu & 412 & 322,9 & 412,16 & 406,82 & 415,06 \\
\hline 8. & WulaWaijelu & 442 & 223,7 & 442,43 & 429,42 & 438,12 \\
\hline 9. & Rindi & 1.116 & 773 & $1.116,05$ & $1.118,79$ & $1.141,40$ \\
\hline 10. & Umalulu & 2.027 & 1,261 & $2.026,93$ & $2.034,11$ & $2.075,30$ \\
\hline 11. & Pandawai & 1.298 & 792,7 & $1.298,23$ & $1.299,57$ & $1.325,89$ \\
\hline 12. & Kota Waingapu & 1.731 & $2.840,5$ & $1.730,97$ & $1.728,99$ & $1.764,00$ \\
\hline 13. & Kambera & 474 & 187 & 598,58 & 598,93 & 611,05 \\
\hline 14. & Haharu & 1.156 & $1.652,2$ & 1.156 & $1.163,96$ & $1.187,53$ \\
\hline 15. & Kanatang & 1,184 & $1.528,5$ & $1.183,84$ & $1.186,57$ & $1.210,59$ \\
\hline & Sumba Timur & 11.166 & $10.387,6$ & $11.290,65$ & $11.300,42$ & $11.503,58$ \\
\hline
\end{tabular}

Sumber : Sumba Timur Dalam Angka, 2013; DKP Kabupaten Sumba Timur

BerdasarkanTabel 1 di atas terlihat bahwa produksi yang dihasilkan nelayan sebagai sector perikanan tangkap kurang berkembang. Tahun 2009 perkembangan jumlah hasil tangkapan dari tahuns ebelumnya mengalami perkembangan sebesar $(6,97)$ \%.Untuk tahun 2010 produksi perikanan tangkap mengalami peningkatan sebesar 8,69\%, tahun 2011 produksi perikanan tangkap tetap menagalami peningkatant etapi relative kecil yakni sebesar 0,09\%.Untuk tahun 2012 produksi perikanan tangkap di wilayah pesisir di Kabupaten Sumba Timur sebesar $1,80 \%$. Hasil analisis menunjukkan bahwa selama lima tahun terakhir dari tahun 2008 sampai 2009 perkembangan nilai kuantitas produksi perikanan tangkap di Kabupaten Sumba Timursebesar $1,27 \%$ per tahun. Nilai ini 
sangat rendah sehingga perlu dilakukan terobosan baruguna meningkat kanproduksi yang dihasilkan nelayan.

\subsection{Armada Perikanan Tangkap}

Jumlah hasil tangkap selain dipengaruhi oleh cuaca juga ditentukan oleh jenis armada yang digunakan oleh nelayan dalam menangkapikan. Semakin baik armada yang digunakan untuk menangkapikan maka jangkauan operasi di laut semakin jauh serta jenisikan yang ditangkap semakain beragam. Kondisi armada penangkapan ikan bagi nelayan di Kabupaten Sumba Timur disajikan pada table dibawah ini. Jenis armada yang digunakan masyarakat pesisir di Kabupaten Sumba Timur terdiri dari perahutanpa motor, perahu motor temple, kapal motor dan motor dalam. Adapun jenis dan jumlah armada yang digunakan masyarakat dapat dilihat pada table berikut.

Tabel 2.Keadaan Armada PenangkapanNelayan di Kabupaten Sumba Timur, 2013

\begin{tabular}{|c|l|r|r|r|r|}
\hline \multirow{2}{*}{ No. } & \multicolumn{1}{|c|}{ Kecamatan } & \multicolumn{4}{|c|}{ JenisdanJumlah Armada PenangkapanIkan } \\
\cline { 3 - 6 } & & $\begin{array}{c}\text { PerahuTanpa } \\
\text { Motor }\end{array}$ & $\begin{array}{c}\text { Perahu Motor } \\
\text { Tempel }\end{array}$ & KapalMotor & $\begin{array}{c}\text { Motor } \\
\text { Dalam }\end{array}$ \\
\hline 1. & LewaTidahu & 6 & 0 & 0 & 0 \\
\hline 2. & KatalaHamuLingu & 4 & 1 & 1 & 0 \\
\hline 3. & Tabundung & 93 & 3 & 3 & 0 \\
\hline 4. & PinuPahar & 55 & 9 & 2 & 2 \\
\hline 5. & Karera & 18 & 16 & 39 & 16 \\
\hline 6. & NgaduNgala & 9 & 0 & 0 & 0 \\
\hline 7. & PahungaLodu & 58 & 14 & 10 & 3 \\
\hline 8. & WulaWaijelu & 64 & 6 & 2 & 1 \\
\hline 9. & Rindi & 112 & 33 & 16 & 12 \\
\hline 10. & Umalulu & 162 & 55 & 28 & 21 \\
\hline 11. & Pandawai & 157 & 16 & 9 & 7 \\
\hline 12. & Kota Waingapu & 110 & 67 & 79 & 79 \\
\hline 13. & Kambera & 35 & 19 & 8 & 6 \\
\hline 14. & Haharu & 114 & 26 & 13 & 13 \\
\hline 15. & Kanatang & 104 & 53 & 13 & 13 \\
\hline & Sumba Timur & 1.101 & 318 & 223 & 143 \\
\hline
\end{tabular}

Sumber : Sumba Timur Dalam Angka, 2013

Berdasarkan Tabel 2 di atas menunjukkan bahwa jumlah armada yang digunakan oleh masyarakat pesisir di Kabupaten Sumba Timur masih relative sedikit. Untuk perahu tanpa motor hanya 1.101 unit yang tersebar pada 15 wilayah kecamatan pesisir.

\subsection{Jenis dan Jumlah Alat Tangkap}

Berdasarkan data tahun 2013, ditetapkan jenis dan jumlah alat tangkap nelayan di Kabupaten Sumba Timur, sebagaimana disajikan pada tabel berikut ini: 
Tabel 3. Jenis Alat Tangkap Nelayan di Kabupaten Sumba Timur, 2012

\begin{tabular}{|c|l|c|}
\hline No. & \multicolumn{1}{|c|}{ NamaAlatTangkap } & Jumlah(unit) \\
\hline 1. & Giil Net Tetap & 63 \\
\hline 2. & Giil Net Hanyut & 9.630 \\
\hline 3. & JalaTebar & 392 \\
\hline 4. & PukatCincin + Lampara & 11 \\
\hline 5. & PukatCumiPayang & 60 \\
\hline 6. & Pancing & 5.932 \\
\hline 7. & JalaWaring & 28 \\
\hline 8. & Se'ro & 15 \\
\hline
\end{tabular}

Sumber : Sumba Timur Dalam Angka, 2013

\subsection{Analisis pemetaan daerah penangkapan}

3.5.1. Daerah penangkapan ikan pelagis Hasil analisis Daerah penangkapan ikan pelagis yang dilakukan ditetapkan ada 2 jalur daerah penangkapan diantaranya adalah daerah penangkapan ikan pelagis pada jalur 1.A yang terletak hampir di semua perairan, di 15 kecamatan pesisir, mulai dari batas karang hingga ke 2 mil dari garis pantaidan daerah penangkapan ikan pelagis pada jalur 1.Byang terletak hampir di semua perairan, di 15 kecamatan pesisir, mulai dari 2 mil dari garis pantai hingga ke 4 mil.
Kabupaten Sumba Timur yang berada di Provinsi NTT memiliki wilayah perairan laut yang luas dan memiliki potensi sumberdaya perikanan tangkap yang sangat melimpah. Berdasarkan Kriteria kesesuaian hasil analisis daerah penangkapan ikan pelagis di perairan Kabupaten Sumba Timur pada kriteria sangat sesuai (S1) memiliki luas 163.464 47 Ha, sesuai (S2) memiliki luas 44.724,60 Ha, kurang sesuai (S3) memiliki luas 11.707,62 dan tidak sesuai (N) 33.769,34. Pada kriteria sangat sesuai terlihat menyebar pada selatan Sumba Timur, kemudian bagian utara dan timur Sumba Timur. Untuk lebih detailnya dapat dilihat pada peta berikut ini:

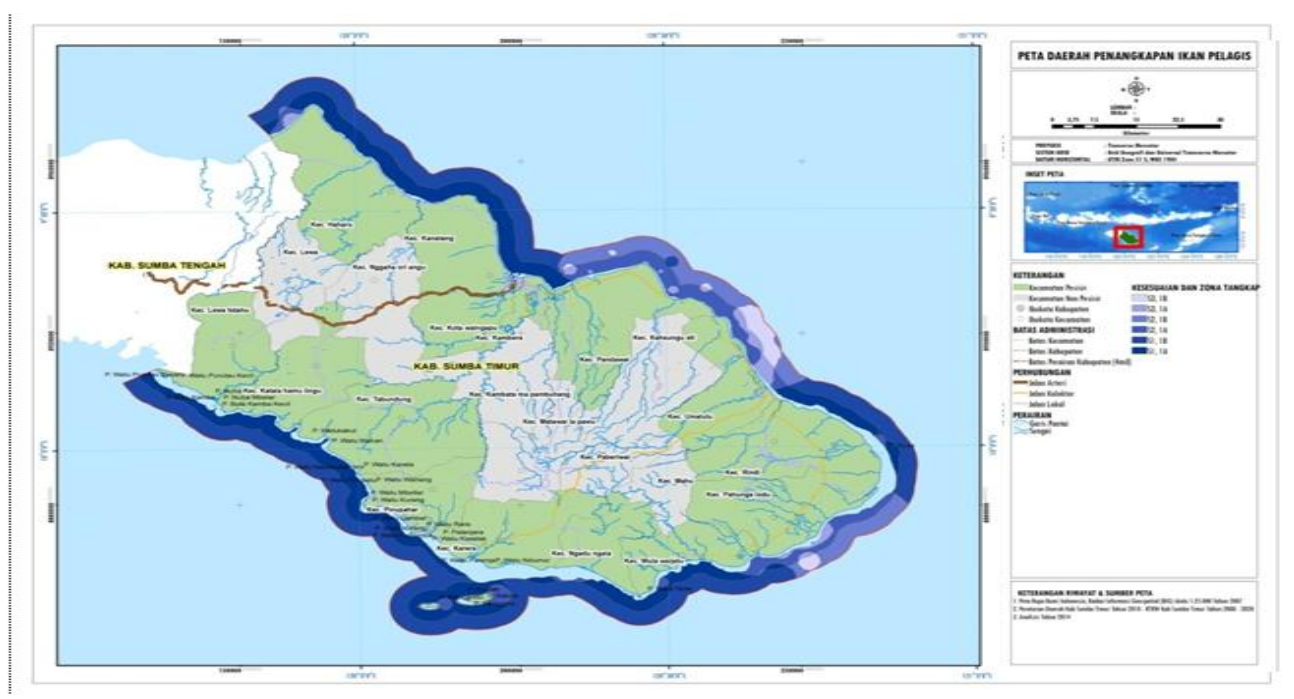

Gambar1. Peta Kesesuaian Penangkapan Ikan Pelagis di Kabupaten Sumba Timur 
3.5.2. Daerah penangkapan ikan demersal

$$
\text { Hasil analisis daerah }
$$

penangkapan ikan demersal ditetapkan lokasi yang tersebar pada hampir semua daerah pesisir,kecuali di perairan Kecamatan Lewa Tidahu, Kecamatan Katala Hamu Lingu, Kecamatan Tabundung terutama perairan yang tidak terdapat ekosistem terumbu karangnya.

Berdasarkan kriteria kesesuaian penangkapan ikan demersal pada perairan Kabupaten Sumba Timur pada kriteria sangat sesuai (S1) memiliki luas 7.109,89 Ha, sesuai (S2) memiliki luas 6.386,77 Ha, kurang sesuai (S3) memiliki luas $11.233,14$ Ha dan tidak sesuai (N) 228.930,59 Ha.Kesesuaian penangkapan ikan demersal dapat terlihat pada sisi timur Kabupaten Sumba Timur yaitu pada perairan Kecamatan Umalulu, Rindi, dan Pahunga Lodu, kemudian disisi utara yaitu pada perairan Kecamatan Kambera dan Pandawai.

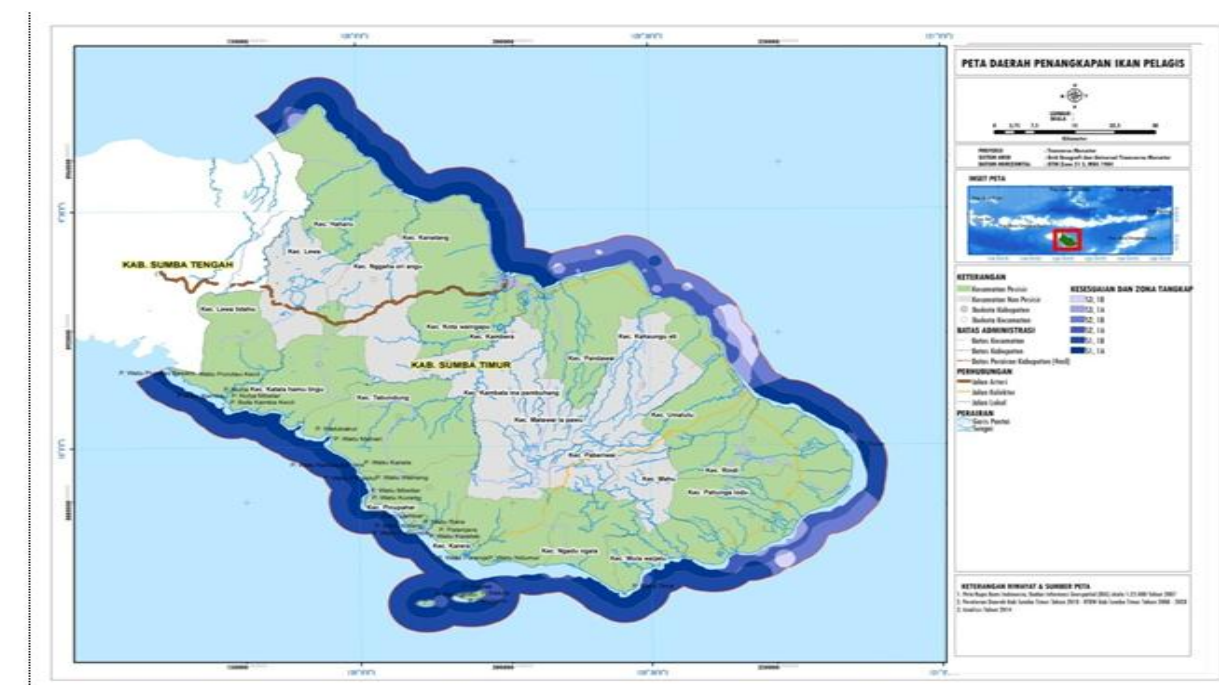

Gambar2. Peta Kesesuaian Penangkapan Ikan Pelagis di Kabupaten Sumba Timur

\section{KESIMPULAN}

Berdasarkan pembahasan yang dilakukan ditetapkan kesimpulan bahwa Kabupaten Sumba Timur memiliki wilayah perairan laut yang luas dan potensi sumberdaya perikanan tangkap yang sangat melimpah, dan produksi ikan tahun 2014, belum optimal. Hasil analisis kesesuaian daerah penangkapan ikan pelagis ditetapkan "sangat sesuai" (S1) 163.46447 Ha, “sesuai” (S2) 44.724,60 Ha, kurang sesuai (S3) 11.707,62. Kesesuaian daerah penangkapan ikan demersal pada kriteria "sangat sesuai" (S1) 7.109,89 Ha, "sesuai" (S2) 6.386,77 Ha, dan kurang sesuai (S3) 11.233,14 Нa. 


\section{DAFTAR PUSTAKA}

[DKP] Dinas Kelautan dan Perikanan Kabupaten Sumba Timur, 2014. Data Statistik Perikanan Kabupaten Sumba Timur.

[DKP] Dinas Kelautan dan Perikanan Kabupaten Sumba Timur, 2011. Masterplan Kawasan Minapolitan Kabupaten Sumba Timur, tahun 2011

Balai Pengelolaan Sumberdaya Pesisir dan Laut [BPSPL] Denpasar. 2014. Penyusunan Dokumen Awal Rencana Zonasi Wilayah Pesisir dan Pulau-Pulau Kecil Kabupaten Sumba Timur.

Ihsan, 2015. Pemanfaatan Sumberdaya Perikanan Rajungan secara berkelanjutan di perairan Kabupaten Pangkep. Disertasi. Program Studi Sistem dan Pemodelan Perikanan Tangkap, Departemen Pemanfaatan Sumberdaya Perikanan FPIK Institut Pertanian Bogor.

Waingapu dalam Angka 2014. Badan Pusat Statistik [BPS] Kabupaten Sumba Timur. 